University of Wollongong

Research Online

Faculty of Engineering - Papers (Archive)

Faculty of Engineering and Information

Sciences

$1-1-2010$

\title{
The behaviour of ballasted track foundations: Track drainage and geosynthetic reinforcement
}

\author{
Buddhima Indraratna \\ University of Wollongong, indra@uow.edu.au \\ Sanjay Nimbalkar \\ University of Wollongong, sanjayn@uow.edu.au \\ Nayoma Chulani Tennakoon \\ University of Wollongong, nayoma@uow.edu.au
}

Follow this and additional works at: https://ro.uow.edu.au/engpapers

Part of the Engineering Commons

https://ro.uow.edu.au/engpapers/880

\section{Recommended Citation}

Indraratna, Buddhima; Nimbalkar, Sanjay; and Tennakoon, Nayoma Chulani: The behaviour of ballasted track foundations: Track drainage and geosynthetic reinforcement 2010, 2378-2387.

https://ro.uow.edu.au/engpapers/880

Research Online is the open access institutional repository for the University of Wollongong. For further information contact the UOW Library: research-pubs@uow.edu.au 


\title{
The Behaviour of Ballasted Track Foundations: Track Drainage and Geosynthetic Reinforcement
}

\author{
Buddhima Indraratna ${ }^{1}$, F. ASCE, Sanjay S. Nimbalkar ${ }^{2}$ and Nayoma Tennakoon ${ }^{3}$ \\ ${ }^{1}$ Professor of Civil Engineering, Faculty of Engineering, Univ. of Wollongong, \\ Wollongong City, NSW 2522, Australia (corresponding author). email: \\ indra@uow.edu.au \\ ${ }^{2}$ Research Associate, Faculty of Engineering, Univ. of Wollongong, Wollongong \\ City, NSW 2522, Australia. email: sanjayn@uow.edu.au \\ ${ }^{3}$ Doctoral student, Faculty of Engineering, Univ. of Wollongong, Wollongong City, \\ NSW 2522, Australia. email: nct096@uow.edu.au
}

\begin{abstract}
Ballasted Rail tracks are widely used throughout the world due to its resiliency to the repeated wheel loads, low construction cost and ease of maintenance. However, the ballast layer needs periodic maintenance due to its deformation and degradation associated with particle breakage and fouling. A proper understanding of the contamination due to various types of fines and its implications on track drainage is a pre-requisite for effective implementation of track maintenance operations. A new parameter Void Contaminant Index (VCI) can accurately assess the contamination as it includes the effect of void ratio, specific gravity and gradation of ballast and fouling material. A series of constant head hydraulic conductivity tests using a specially designed large-scale permeability apparatus were performed on fresh ballast mixed with different proportions of fines to study the relationship between the percentage of fouling and drainage characteristics. A field trial is conducted on an instrumented track at Bulli, NSW Australia, to study the benefits of a geocomposite layer installed at the ballastcapping interface, and to evaluate the performance of recycled ballast in comparison to traditionally uniform fresh ballast. It is found that recycled ballast can be effectively reused if reinforced with a geocomposite. The geocomposite can effectively reduce vertical and lateral deformations of the ballast with obvious implications on improved track stability thereby reducing maintenance costs.
\end{abstract}

\section{INTRODUCTION}

For the safe and efficient operation of ballasted rail tracks, proper maintenance guidelines to keep ballast layer clean and freely draining are of paramount importance. Ballast is the selected crushed uniformly graded granular material having a large pore structure to facilitate efficient and fast drainage. However, after a certain period, ballast becomes contaminated and drainage is significantly impaired. The problems associated with ballast fouling are mainly attributed to fines containing sand, silt, clay and coal fines. In Australia, Queensland 
Rail network suffers degradation of track mainly due to the surface infiltration of coal fines due to spilling of coal wagons. When the voids in the ballast are intruded with fines, the ballasted track may not perform its intended functions effectively.

Several fouling indices are used in practice for measurement of fouling. Selig and Waters (1994) have defined the fouling index as a summation of percentage (by weight) passing the $4.75 \mathrm{~mm}$ sieve and $0.075 \mathrm{~mm}$ sieve. They also proposed percentage of fouling which is the ratio of the dry weight of fouled material passing $9.5 \mathrm{~mm}$ sieve to the dry weight of total fouled ballast sample. Ionescu (2004) modified the fouling index as a summation of percentage (by weight) passing the $13.2 \mathrm{~mm}$ sieve and $0.075 \mathrm{~mm}$ sieve to suit the Australian Rail Track conditions. All the above mass based indices give a false measurement of fouling, when the fouling material has a different specific gravity. Therefore, Feldman and Nissen (2002) defined the Percentage Void Contamination (PVC) as the ratio of bulk volume of fouling material to the volume of voids of ballast when it is clean. However, this PVC method does not consider the effect of void ratio, gradation and specific gravity of fouling material, which is the main factor affecting ballast drainage. Therefore, a new parameter Void Contaminant Index (VCI) is proposed to incorporate effects of void ratio, specific gravity and gradation of fouling material and ballast.

The use of geosynthetics in rail tracks has been studied in the past, and it is proved that geosynthetics can improve the track performance by reducing deformation and degradation (Rowe and Jones, 2000, Raymond, 2002, Indraratna and Salim, 2003, 2005, Indraratna et al., 2004). In order to understand the stressdistribution and strain accumulation in various layers of the track substructure under repeated wheel loads, a field trial was conducted in the town of Bulli, north of Wollongong city. The objectives of this instrumented field trial were to study the benefits of a geocomposite installed at the ballast-capping interface, and to examine the performance of recycled ballast in comparison to the traditionally uniform fresh ballast. University of Wollongong provided the technical specifications for the design of the instrumented track to RailCorp, Sydney who sponsored the research project. In this paper, the behavior of ballasted track with reference to track drainage and geosynthetic reinforcement is discussed in detail.

\section{PERMEABILITY AND TRACK DRAINAGE}

Ballast is a free draining material with size ranging from $10 \mathrm{~mm}$ to $63 \mathrm{~mm}$ and contains large voids space. However, the infiltration of fouling material reduces the voids space and restricts track drainage. Studies have been conducted to investigate the effect of sand, silt and clay fines (Wallace, 2003) and coal fines on the permeability and track drainage. Recently, a new parameter defined as Void Contaminant Index (VCI) is proposed, which includes the effect of void ratio, specific gravity and gradation of ballast and fouling material defined as:

$$
V C I=\frac{\left(1+e_{f}\right)}{e_{b}} \times \frac{G_{s b}}{G_{s f}} \times \frac{M_{f}}{M_{b}} \times 100
$$


where, $e_{b}, G_{s b}$ and $M_{b}$ are void ratio, specific gravity and dry mass of clean ballast, respectively, and $\mathrm{e}_{\mathrm{f}}, \mathrm{G}_{\mathrm{sf}}$ and $\mathrm{M}_{\mathrm{f}}$ are void ratio, specific gravity and dry mass of fouling material, respectively.

The specifications of clean ballast vary widely for different railway organizations throughout the world. Therefore the changes in void ratio, specific gravity and gradation of clean ballast are expected. However, all ballast specifications generally demand a uniform gradation (uniformity coefficient, $\mathrm{C}_{\mathrm{u}}=$ 1.5-3.0) to fulfill the requirements of rapid track drainage. Also, void ratio of clean ballast $\left(\mathrm{e}_{\mathrm{b}}\right)$ will not change significantly. However, there is significant variation in the void ratio, specific gravity and gradation characteristics of fouling material such as sand, silt, clay and coal fines, and VCI can take into account all such variations.

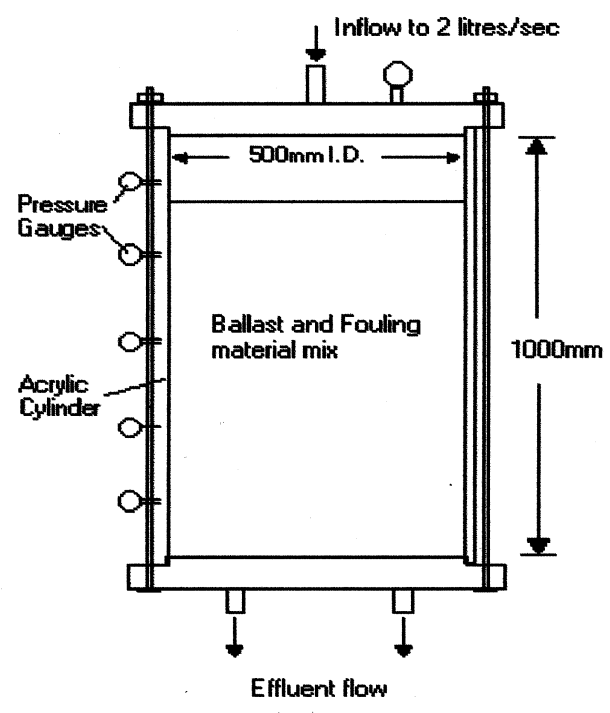

(a) Schematic diagram (Wallace, 2003)

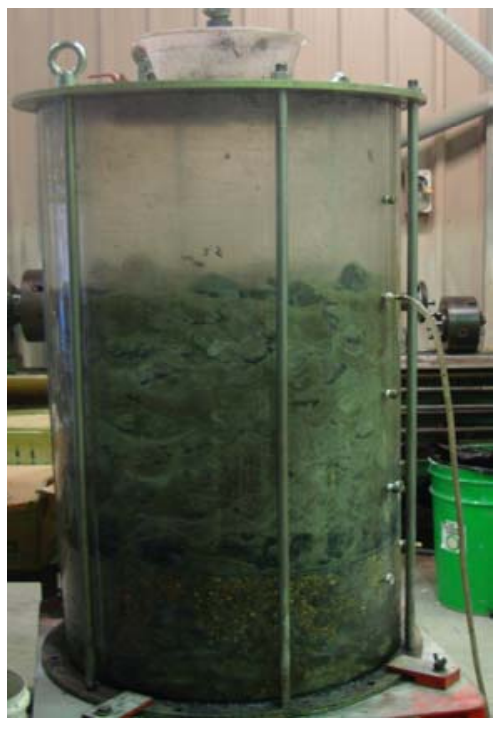

(b) Test set-up

Figure 1. Large scale permeameter

A series of large-scale constant head permeability tests for different percentage of fines were conducted. A large-scale permeameter that accommodates a specimen of $500 \mathrm{~mm}$ in diameter and $1000 \mathrm{~mm}$ in height was used (Figure 1). The clean ballast was prepared as per current industry practices (Standards Australia, 1996). The sand fines and coal fines were selected as well graded. The low plastic silt fines $(\mathrm{IP}=7)$ and intermediate plastic clay fines $(\mathrm{IP}=17)$ were used. Figure 2 illustrates the particle size distribution of these materials. The clean ballast was compacted to an initial density of about $1600 \mathrm{~kg} / \mathrm{m}^{3}$ to simulate the field conditions. The initial void ratio of clean ballast was $0.72-0.75$. The discharges and piezometers readings were continually recorded.

The values of hydraulic conductivity of fouled ballast are plotted against percentage of fouling as shown in Figure 3. The VCI values are also plotted in Figure $3 \mathrm{~b}$. As expected, the hydraulic conductivity of fouled ballast shows a reduction with 
increase in the value of percentage of fouling. As evident from Figure 3b, mass based index, i.e. percentage of fouling, underestimates the fouling of ballast due to the lower specific gravity of coal fines. In this context, the VCI captures the fouling of ballast accurately.

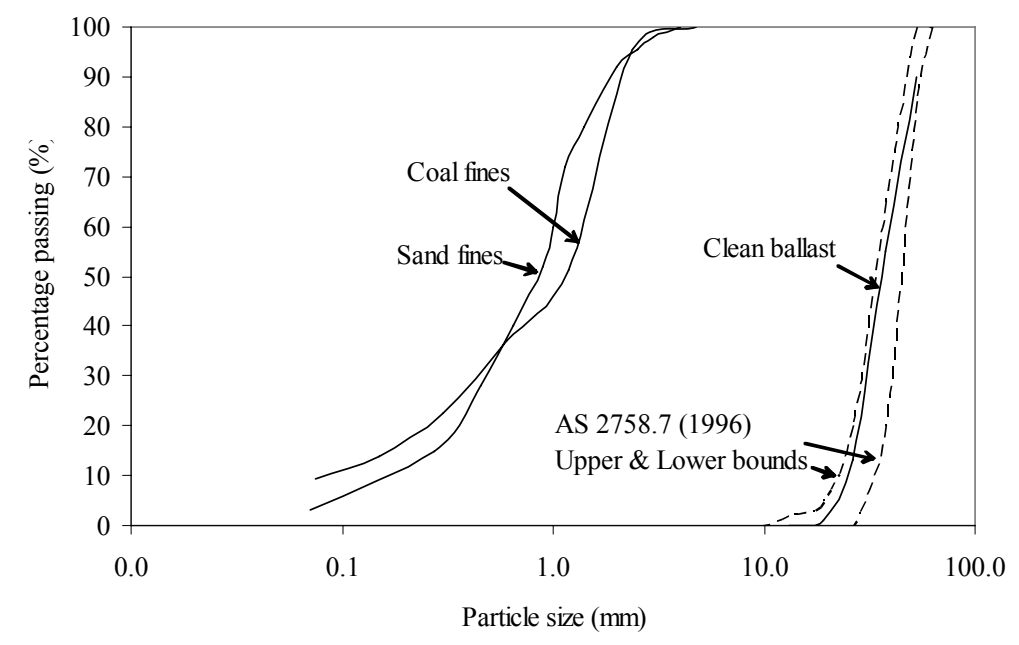

Figure 2. Gradation of clean ballast, coal fines and sand fines

An increase in percentage of fines, should result in a decrease in hydraulic conductivity, because, the fine particles accumulated in voids impede the free draining capacity of ballast. A sharp decrease is observed at relatively low values of percentage of fouling as illustrated in Figure 3. This indicates the significant reduction in the permeability with very small intrusion of fines.

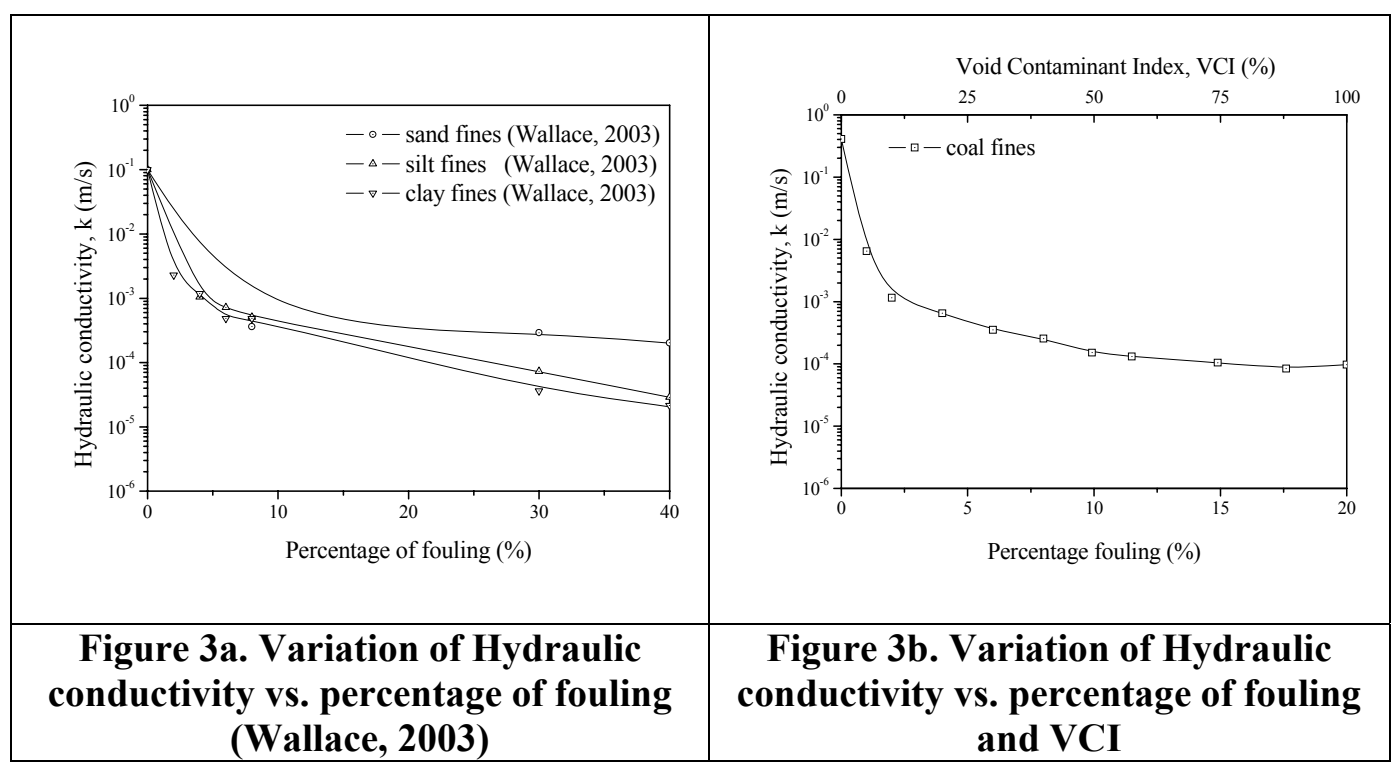


It is observed that coarse fouling material such as sand does not have a significant effect on the hydraulic conductivity of ballast. Clay, coal and silt fines have proven to cause significant reduction in the hydraulic conductivity and impede drainage of the ballast bed. The relative hydraulic conductivity ratio is defined as the ratio of hydraulic conductivity of clean ballast to that of fouled ballast. The $k_{b} / k$ ratio indicates how many times the overall hydraulic conductivity of fouled ballast may reduce compared to that of clean ballast. Figure 4 shows the effect of percentage of fouling on the relative hydraulic conductivity ratio $\left(k_{b} / k\right)$. It indicates that sand fines have the least hydraulic conductivity ratio, and clay fines have the highest hydraulic conductivity ratio.

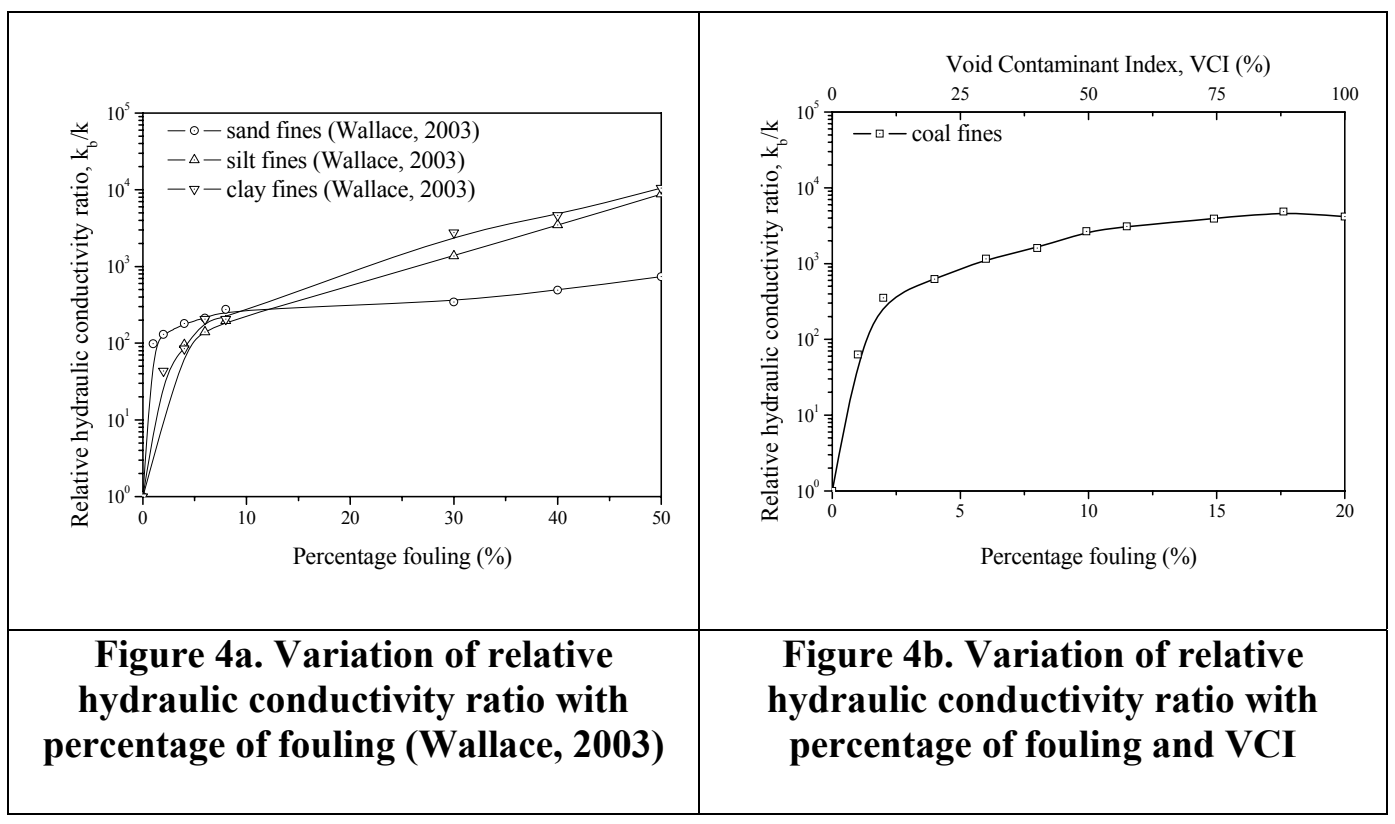

The $k_{b} / k$ ratio can be considered as the key to govern the drainage condition of ballast. The greater the $k_{b} / k$ ratio is, the higher will be the reduction of the track hydraulic conductivity. When the overall hydraulic conductivity is less than $10^{-4} \mathrm{~m} / \mathrm{s}$, the drainage condition is considered as poor. Generally, the average hydraulic conductivity of clean ballast is $0.3 \mathrm{~m} / \mathrm{s}$. Therefore, the critical $k_{b} / k$ ratio for poor drainage can be taken as approximately 3000 .

\section{GEOSYNTHETIC REINFORCEMENT}

The accurate prediction of a typical rail track maintenance cycle warrants comprehension of the complex mechanisms associated with track deterioration. To date, most of the design methods are based on conservative estimates of settlements and stress-transfer between the track layers. Given the complexities of the behavior of the composite track system consisting of rail, sleeper, ballast and sub-ballast under repeated traffic loads, the current track design techniques are overly simplified. To study the potential benefits of gesynthetics in rail track, a field study was undertaken. The track was constructed between two turnouts at Bulli along the coast of New 
South Wales, north of Wollongong city. The total length of the instrumented track section was $60 \mathrm{~m}$, and it was divided into four sections, each $15 \mathrm{~m}$ in length. Two sections were built without the inclusion of a geocomposite layer, while remaining sections were built by placing a geocomposite layer at the base of the fresh and recycled ballast, respectively [Figure 5].

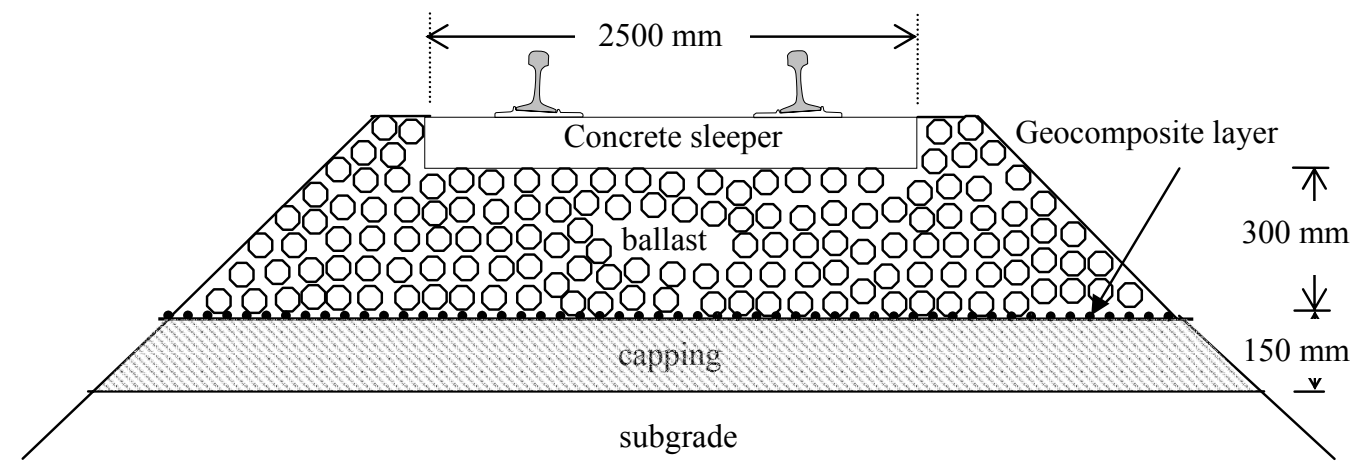

Figure 5. Section of ballasted track bed with geocomposite layer at the ballastcapping interface.

The overall track bed thickness was kept as $450 \mathrm{~mm}$ including a ballast layer of $300 \mathrm{~mm}$ and a capping layer of $150 \mathrm{~mm}$ in thickness. The particle size, gradation, and other index properties of ballast used at the Bulli site were in accordance with the Technical Specification TS 3402 (Railcorp, Sydney), which represents sharp angular coarse aggregates of crushed volcanic basalt (latite). Recycled ballast was collected from a recycled plant commissioned by Railcorp at their Chullora yard near Sydney. Table 1 shows the grain size characteristics of fresh ballast, recycled ballast and the capping materials used in the Bulli instrumented track (Indraratna and Salim, 2003, Ionescu, 2004). Concrete sleepers were used in the test track. Electrical Friction Cone Penetrometer (EFCP) tests reported that the subgrade soil is a stiff overconsolidated silty clay and had more than sufficient strength to support the train loads. The bedrock is a highly weathered sandstone having weak to medium strength.

Table 1. Grain size characteristics of fresh ballast, recycled ballast and capping materials (Indraratna and Salim 2005; Ionescu, 2004)

\begin{tabular}{|l|c|c|c|c|c|c|}
\hline Material & Particle shape & $\boldsymbol{d}_{\boldsymbol{m a x}}(\mathbf{m m})$ & $\boldsymbol{d}_{\boldsymbol{m i n}}(\mathbf{m m})$ & $\boldsymbol{d}_{\mathbf{5 0}}(\mathbf{m m})$ & $\boldsymbol{C}_{\boldsymbol{u}}$ & $\boldsymbol{C}_{\boldsymbol{c}}$ \\
\hline Fresh Ballast & Highly angular & 75.0 & 19.0 & 35.0 & 1.5 & 1.0 \\
\hline Recycled Ballast & Semi-angular & 75.0 & 9.5 & 38.0 & 1.8 & 1.0 \\
\hline Capping & Angular to rounded & 19.0 & 0.05 & 0.26 & 5.0 & 1.2 \\
\hline
\end{tabular}

A bi-axial geogrid was placed over the non-woven polypropylene geotextile to serve as the geocomposite layer, which was installed at the ballast-capping interface. The technical specifications of geosynthetic material used at the site can be found elsewhere (Indraratna and Salim, 2005). To measure the vertical and horizontal deformations of ballast, settlement pegs and displacement transducers 
were installed at the sleeper-ballast and ballast-capping interfaces in different track sections. The vertical and horizontal stresses developed in the track bed under repeated wheel loads were measured by pressure cells (230 $\mathrm{mm}$ diameter) installed at locations in section of fresh ballast.

\section{Average vertical and lateral deformations of ballast layer}

In order to investigate the overall performance of the ballast layer, the average vertical deformation $\left(S_{v}\right)_{a v g}$ was considered by taking the mean of measurements taken under the rail and the edge of sleeper at each interface. The values of $\left(S_{v}\right)_{a v g}$, are plotted against the number of load cycles $(N)$ in Figure 6 and in the recycled ballast they are smaller compared to the case of fresh ballast. The better performance of selected recycled ballast can benefit from less breakage as they are often less angular, thereby preventing corner breakage due to high contact stresses. The recycled ballast is moderately-graded than the relatively uniform fresh ballast. For granular materials, an increased uniformity coefficient $\left(\mathrm{C}_{\mathrm{u}}\right)$ leads to a more compact packing arrangement (i.e. reduced void ratio). For example, Selig and Waters (1994) have shown that a more well-graded ballast with higher $C_{u}$ can significantly reduce the settlement. Therefore, it is not surprising that the recycled ballast gives less displacements due to its higher $\mathrm{C}_{\mathrm{u}}$ value compared to fresh ballast, even though the individual recycled ballast particles are more rounded $\left(\phi=43^{0}-54^{0}\right)$ compared to the relatively angular fresh ballast $\left(\phi=46^{0}-69^{0}\right)$. The geocomposite inclusion induces decrease in $\left(S_{v}\right)_{\text {avg }}$ of recycled ballast at a large number of cycles. The load distribution capacity of ballast layer is improved by the placement of a flexible and resilient geocomposite layer which results in a substantial reduction of settlement under high cyclic loading.

Figure 7 shows the average lateral deformation $\left(S_{h}\right)_{a v g}$ of ballast (i.e., determined from the mean of measurements at sleeper-ballast and ballast-capping interfaces) plotted against the number of load cycles $(N)$. The ballast layer exhibits an increase in the average lateral deformation [i.e. lateral spread, represented by negative $\left.\left(S_{h}\right)_{a v g}\right]$ in all sections. The values of $\left(S_{h}\right)_{a v g}$ of recycled ballast show significant decrease compared to fresh ballast. The recycled ballast stabilised with the geocomposite layer exhibits values of $\left(S_{h}\right)_{\text {avg }}$ less than those of unreinforced fresh ballast (i.e. without geosynthetics). Thus, the use of geocomposite is essential in ensuring the reduction of lateral spread of ballast. The favourable confining and reinforcing properties of a geocomposite layer (i.e. geogrid bonded with geotextile drainage layer) improves the lateral stability of ballast. This has a significant bearing on the maintenance of rail tracks. The reduction in the lateral movement of ballast decreases the need for additional layers of crib and shoulder ballast during maintenance. If a greater internal confining pressure in track could be provided via placing a geosynthetic layer within the ballast bed itself, then the lateral deformations of ballast would decrease substantially.

The track substructure is essentially self-supporting with minimal lateral restraints and the effective confining pressure is a key parameter governing the design of railway tracks with implications on ballast movement and associated track 
maintenance (Indraratna and Salim, 2005). Thus, an increase in the track confinement due to use of geosynthetics is a significant factor among several others such as reduction of tamping, leveling and lining associated with ease of maintenance. Fresh ballast with geocomposite showed least deformations (Figs. 6 and 7). This is due to highly frictional, angular particles of fresh ballast which develop increased apparent friction with the geocomposite layer.

The track deterioration is a result of accumulated plastic settlements in the track layers and has serious consequences on the passenger comfort, safety and efficiency (speed restriction) during train operation. The influence of geosynthetics in preventing track deterioration is appealing to railway industry, due to the low cost of geosynthetics in relation to substantial savings generated by the extended track life-cycle and more resilient ballast behaviour.

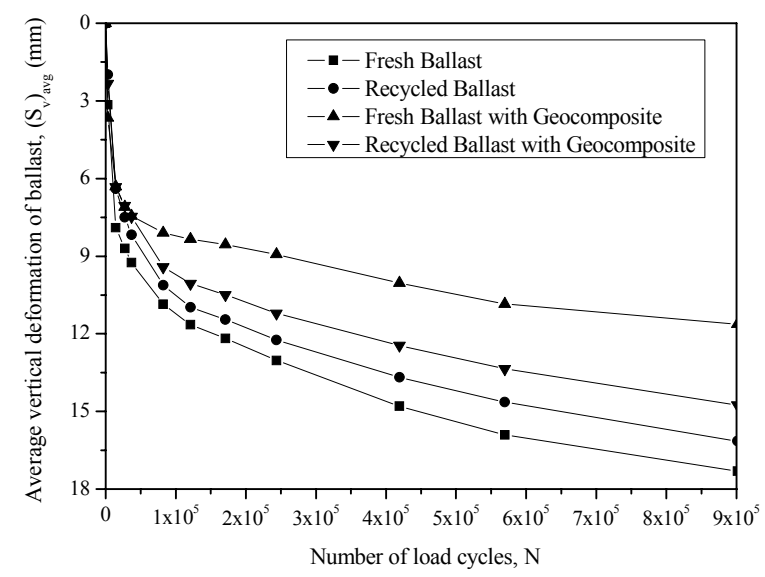

Figure 6. Average vertical deformation $\left(S_{v}\right)_{a v g}$ of the ballast layer

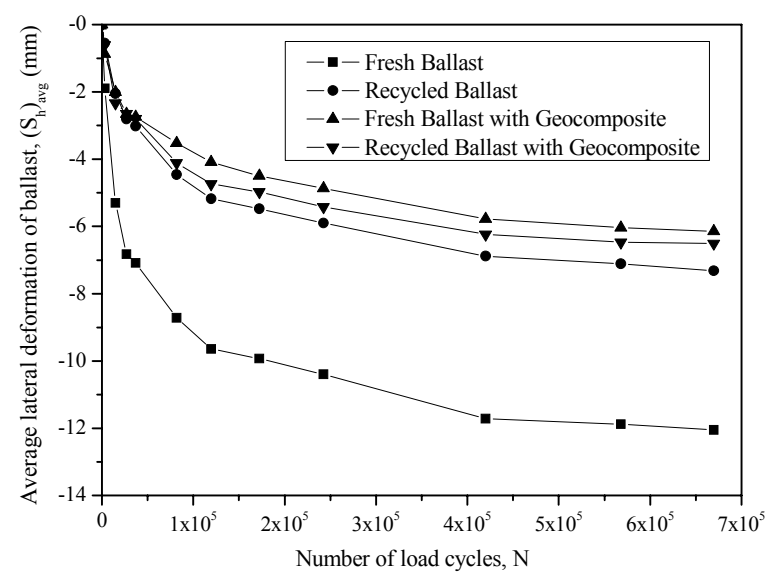

Figure 7. Average lateral deformation $\left(S_{h}\right)_{a v g}$ of the ballast layer 


\section{In-situ stresses across different layers}

Figure 8 shows the vertical and horizontal maximum cyclic stresses beneath the rail $\left(\sigma_{v r}, \sigma_{h r}\right)$ recorded in section of fresh ballast due to the passage of a coal train (25 tons axle load). It is observed that $\sigma_{v r}$ is much higher than $\sigma_{h r}$, thus producing large shear strains in the rail track. These shear strains associated with the horizontal spreading of ballast cause significant vertical compression of the layer (Selig and Waters, 1994). The stress transfer process is shown in Figure 8 at three interfaces, viz. ballast-sleeper, ballast-capping and capping-subgrade interfaces in the rail track.

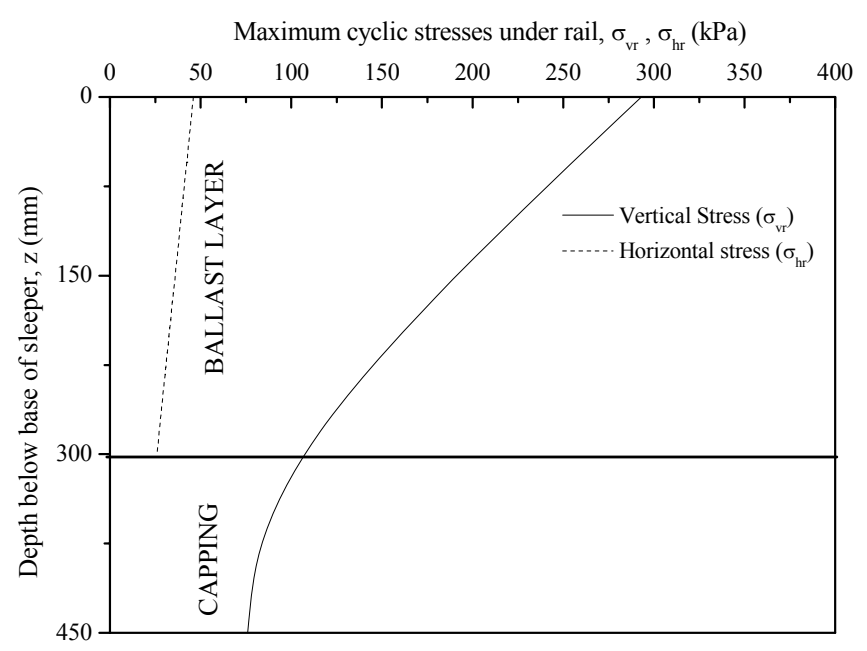

Figure 8. Vertical and horizontal maximum cyclic stresses measured under rail $\left(\sigma_{v r}, \sigma_{h r}\right)$ for coal train with wagons (100 tons)

As expected, high dynamic stresses at the ballast-sleeper interface decrease with depth. It is anticipated that the use of geosynthetic reinforcement would help further the stress transfer process.

\section{CONCLUSIONS}

The performance of rail track with reference to drainage and geosynthetic reinforcement has been discussed. The hydraulic conductivity of ballast is reduced significantly by the intrusion of fines. It is shown that the proposed Void Contaminant Index (VCI) predicts well the extent of ballast fouling. It is found that a small increase in the percentage of fines leads to a significant decrease in the hydraulic conductivity of the ballast layer. The coal, clay and silt fines have shown to cause significant reduction in the hydraulic conductivity. The sand fines show the least impact on the hydraulic conductivity. The field trial conducted at town of Bulli demonstrates the performance of various track layers exposed to repeated wheel loads. It is found that a rail track reinforced with a geocomposite undergoes reduced compression and lateral spread of ballast as compared to conventional (unreinforced) 
track sections. The recycled ballast if selected over a wider particle size distribution produces lesser settlements and strains compared to uniform fresh ballast. The recycled ballast when used with a geocomposite layer is found to perform as well as conventional track (i.e. fresh ballast without a geocomposite), with obvious favourable implications on reduced maintenance costs.

\section{ACKNOWLEDGEMENTS}

The Authors wish to thank the CRC for Rail Innovation, Australia for its continuous support. The significant contributions made by Railcorp (Sydney) during the construction of the instrumented track section is gratefully acknowledged. The past data acquired by students Andrew Wallace and Todd Lyall under the supervision of Professor Indraratna have provided a useful insight to this study. The useful comments and support by Dr. Cholachat Rujikiatkamjorn in preparation of this paper is greatly appreciated.

\section{REFERENCES}

Australian Standard: AS 2758.7 (1996). Aggregates and rock for engineering purposes; Part 7: Railway ballast.

Esveld, C. (2001), Modern Railway Track, MRT-Productions, Netherlands.

Feldman, F. and Nissen, D. (2002). "Alternative Testing Method for the Measurement of Ballast Fouling: Percentage Void Contamination." Conference on Railway Engineering, Wollongong, RTSA: 101-109.

Indraratna, B., Khabbaz, H., Salim, W., Lackenby, J., and Christie, D. (2004). "Ballast characteristics and the effects of geosynthetics on rail track deformation." Proc. Int. Conf. on Geosynthetics and Geoenvironmental Engineering ICGGE 2004, Bombay, India: 3-12.

Indraratna, B. and Salim, W. (2003). "Deformation and degradation mechanics of recycled ballast stabilised with geosynthetics." Soils and Foundations, 43(4), $35-46$.

Indraratna, B. and Salim, W. (2005), Mechanics of ballasted rail tracks - A geotechnical perspective, A. A. Balkema - Taylor and Francis, UK.

Ionescu, D. (2004). Evaluation of the engineering behaviour of railway ballast. $P h D$ thesis, School of Civil, Mining and Environmental Engineering, University of Wollongong, Wollongong.

Raymond G. P. (2002). "Reinforced ballast behaviour subjected to repeated load." Geotextiles and Geomembranes, 20(1): 39-61.

Rowe, P. K. and Jones, CJFP (2000). "Geosynthetics: innovative materials and rational design." In: Proceedings, GEOENG 2000, Melbourne, Australia, 11241156.

Selig, E.T. and Waters, J.M., (1994), Track Geotechnology and Substructure Management, Thomas Telford, London. Reprint 2007.

T. S. 3402: Specification for Supply of Aggregates for Ballast. Rail Infrastructure Corporation of NSW, Sydney, Australia, 2001.

Wallace, A.J., (2003). Permeability of Fouled Rail Ballast. UG Thesis, School of Civil, Mining and Environmental Engineering, University of Wollongong, Wollongong. 